Jurnal Konstruksi Hukum | ISSN: 2746-5055

Vol. 2, No. 2, Mei 2021, Hal. 283-289| Tersedia online di

https://www.ejournal.warmadewa.ac.id/index.php/jukonhum

DOI: https://doi.org/10.22225/jkh.2.2.3223.283-289

\title{
TANGGUNG JAWAB PIDANA KORBAN PEMERKOSAAN ABORSI JANIN DITINJAU DARI PERSPEKTIF HAK ASASI MANUSIA
}

\author{
Ni Luh Putu Sri Laksemi Dharmapadmi, Anak Agung Sagung Laksmi Dewi, I Made Minggu Widyantara \\ Fakultas Hukum Universitas Warmadewa, Denpasar-Bali, Indonesia \\ srilaksmi323@gmail.com, laksmidewi29@gmail.com, mademminggu21@gmail.com
}

\begin{abstract}
Abstrak
Indonesia merupakan Negara hukum yang segala aspek kehidupan warga Negaranya selalu ada aturan maupun norma, baik itu sanksi ataupun tanggungjawab hukum yang ikut serta tumbuh di masyarakat. Tanggungjawab bukan hanya dapat dikenakan kepada pembuat kesalahan namun korban pun dapat memikul hal ini. Dari pemyataan tersebut terdapat permasalahan yaitu mengenai perlindungan hukum terhadap korban pemerkosaan aborsi janin ditinjau dari perspektif HAM dan sanksi pidana terhadap pelaku aborsi janin berdasarkan HAM. Penelitian ini bertujuan untuk mengetahui bagaimana hukum melindungi korban pemerkosaan yang melakukan aborsi janin. Penelitian ini menggunakan metode penulisan hukum normatif yang dimana penulisan ini mengenai asas, norma dan kaidah. Adapun sumber data yang digunakan adalah data primer dan sekunder yang dieroleh yang dieroleh melalui teknik wawancara dan dokumentasi. Hasil penelitian menunjukkan bahwa pemerkosaan yang memutuskan mengaborsi janinnya, hal ini tentunya membuat tanggung jawab dipikul juga oleh sang korban yang mengaborsi janinnya yang dikarenakan oleh pemerkosaan dan menjadikan kehamilan yang tidak dikehendaki yang berujung aborsi. Tentunya hal ini sangat bertentangan dengan hukum pidana maupun hak asasi dari janin itu. Tulisan ini menguraikan bahwa tanggung jawab korban pemerkosaan terhadap janin yang diaborsinya dapat dilihat dari segi hak asasi manusia seorang janin dan korban itu sendiri.
\end{abstract}

Kata Kunci: Aborsi, Hak Asasi Manusia, Korban Pemerkosaan, Pidana.

\begin{abstract}
Indonesia is a Legal State whose all aspects of citizens' lives are always rules and norms, be it sanctions or legal responsibilities that participate in growing in society. Responsibilitycan not only be imposedon the wrongmaker but the victim can shoulder this. From the statement, there are problems, namely the legal protection of victims of fetal abortion rape reviewed from a human rights perspective and criminal sanctions againstfetal abortion perpetrators based on human rights. This study aims to determine how the law of covering rape victims who perform fetal abortion. This writing uses the normative legal writing method where the writing is about principles, norms, and rules. In this writing the rape victim who decided to abort her fetus, this certainly makes the responsibility carried also by the victim who abortions her fetus caused by rape and makes the pregnancy that is not stopped that leads to abortion. Surely this is very contrary to the criminal law as well as the human rights of thefetus. Thispaper describesthat the responsibility of rape victims to the fetus abortion can be seen in terms of the human rights of a fetus and the victim himself.
\end{abstract}

Keywords: Crime, Rape Victims, Abortion, HumanRights

\section{PENDAHULUAN}

Indonesia adalah sebuah negara hukum dan seperti diketahui hukum tidak akan lepas dari masyarakat yang dimana jika tidak ada hukum didalam masyarakat tentunya akan timbul kegaduhan atau tidak adanya sebuah aturan yang mengikat sehingga terjadi konflik dan lain sebagainya. Di dalam masyarakat tentunya akan ada perkembangan,kemajuan dan permasalahan yang terjadi kedepannya, maka atas dasar itulah sebab perlunya peraturan yang mengatur permasalahan nanti kedepannya di dalam masyarakat yang selalu bekembang. Dasarnya adalah bahwa hukum diciptakan untuk membuat atau menjadikan masyarakat untuk tunduk terhadap aturan yang ada dan juga aturan-aturan yang dibuat ini mempunyai sebuah ketegasan pada pelaksanaannya di dalam masyarakat itu sendiri.

Jika disamakan pada keadaan Indonesia sekarang hukum bagaikan dianggap alat perubahan pada masyarakat. Maka sebaiknya hukum itu mengikuti hukurn yang sudah hidup pada masyarakat serta mencontohkannya (Rasjidi \& Rasjidi, 2016 26). Pelaksanaan hukum di Indonesia biasanya menimbulkan banyak permasalahan dalam penegakannya terkadang peraturan yang telah dibuat melenceng dari pelaksanaanya yang terjadi dilapangan dan juga biasanya hukum yang sud ah dibuat mempunyai pertentangan di masyarakat. Membahas tentang pengaturan hukurn pada masyarakat, 
seperti misalnya aturan khusus mengenai hak dari seorang manusia sebagaimana diatur dalam Undang-Undang Republik Indonesia Nomor 39 Tahun 1999 tentang Hak Asasi Manusia. Hal ini seperti yang diketahui bahwa hak asasi manusia ini tidak bersumber dari hukum melainkan dari Tuhan maka hak dari seorang tidak boleh diambil atau dikurangi (Abdullah, 2001;13).

Tetapi perlu disadari bahwa konflik pada hak asasi manusia pasti akan ada atau muncul, seperti salah satunya aborsi yang dilakukan oleh seorang perempuan. Pada dasarnya aborsi ini merupakan sebuah fenomena yang hidup dalam masyarakat Indonesia (Susanti, 2012). Tindak pidana perkosaan erat sekali kaitannya dengan fungsi reproduksi perempuan dan dapat menimbulkan kehamilan yang tidak diinginkan yang kemudian muncullah keinginan untuk melakukan aborsi (Sari, 2013). Pada hukum di Indonesia pengguguran kandungan yang sebagaimana diartikan membuat janin menjadi terbunuh terrnasuk dalam tindak pidana. Melakukan perbuatan aborsi sangat susah untuk dibuktikan dengan pihak yang menangani atau yang berwajib. Pada kenyataanya melakukan tindakan ini selalu dilaksanakan dengan sembunyi agar tidak ketahuan. Legalisasi aborsi perlu diperhatikan lebih bijak tetapi bukan dalam pengertian memberikan liberalisasi aborsi (Utami \& Mulyana, 2015).

Dasar alasan yang menjadikan seseorang terdorong melakukan hal ini dikarenakan tidak menginginkan janin atau bayi ini lahir karena hasil hubungan gelap atau tidak ingin memiliki bayi dikarenakan faktor ekonomi dan lain sebagainya yang membuat terdorongnya seseorang melakukan aborsi. Tetapi ada beberapa pihak setuju terhadap aborsi ini seperti dokter yang mengharapkan orang tersebut atau seorang ibu untuk melakukan tindak aborsi dikarenakan kepentingan mental dari ibu yang sudah diperkirakan sebelumnya akan berbahaya ketika melahirkan bayi. Tapi bagi yang tidak setuju aborsi pastinya dianggap perbuatan yang membunuh diri seorang yang tidak bersaJah dan apalagi yang dilakukan itu terhadap janin yang masih ada didalam kandungan. Penelitian ini bertujuan untuk mengetahui bagaimana hukum memayungi korban pemerkosaan yang melakukan aborsis janin. Dari uraian permasalahan sebelumnay, penelitian ini dilakukan dengan tujuan untuk menjelaskan perlindungan hukum terhadap korban pemerkosaan aborsi janin ditinjau dari perspektif HAM dan mengetahui sanksi pidana terhadap pelaku aborsi janin berdasarkan HAM

\section{METODE PENELITIAN}

Penelitian ini menggunakan penelitian secara normatif yang mana mengacu pada studi kepustakaan di bidang hukum, dengan menggunakan pendekatan masalah secara konseptual dan pendekatan kasus yang terjadi. Penelitian ini menggunakan data primer data sekunder dan data tersier. Data primer berpedoman terhadap undang-undang dan keputusan yang mengikat. Data hukum sekunder didapatkan melalui jurnal hukum, buku hukurn, serta internet yang memuat mengenai perubahan status jenis kelamin dalam perspektif hukum positif di Indonesia. Sedangkan data tersier didapatkan melalui kamus hukum serta ensiklopedia yang berkaitan mengenai informasi hukum. Teknik pengumpulan data yaitu dengan cara mencatat, mengutip, membaca, maupun meringkas literatur yang mengacu terhadap perubahan status jenis kelamin di Indonesia. Penulis melakukan metode Analisa untuk Menganalisis setiap bahan buku yang dipergunakan untuk mernilih yang sesuai dengan topik dari penelitian yang mana akan di analisis dengan sistematis dan mengaitkannya dengan bahan hukum lainnya.

\section{HASIL DAN PEMBAHASAN}

\section{Perlindungan Hukum terhadap Korban Pemerkosaan Aborsi Janin Ditinjau dari Perspektif Hak Asasi Manusia}

Menurut Esman dalam (Sofian, 2011) aborsi adalah keadaan terputusnya suatu kehamilan dimana fetus belum sanggup berdiri sendiri diluar uterus. Keadaan inilah yang membuat aborsi dilarang di Indonesia, keadaan tersebut dianggap sama dengan menghilangkan nyawa. Ada beberapa hal yang bisa dilakukan untuk melakukan atau melindungi seorang yang sudah melakukan pengguguran atau yang disebut aborsi ini. Sebelumnya pada intinya menegaskan hukum pidana tak dapat dipisahkan pada keikutsertaan negara menjadi institusi pada kewenangannya bisa mengaktifkan atau menghidupkan penegakan hukum pidana yang terjadi pada masyaraka (Duwi Handoko, 207: 33). Memberikan suatu mengenai perlindungan hukum tentunya agar masyarakat merasa dilindungi serta memberikan rasa nyaman kepada orang lain agar tidak terjadi hak asasi seorang manusia diambil atau dikurangi yang tentunya menjaga hak asasi manusia itu sendiri. Bukan hanya itu saja tetapi 
perlindungan ini akan menciptakan suatu kenyamanan baik itu secara fisik maupun secara non fisik serta ancaman dari orang lain yang ingin mengganggu kenyamanan.

Dalam pelaksanaanya perlindungan ini juga diatur dalam Pas al 28 D ayat (1) pada dasamya pasal tersebut menjelaskan bahwa memang setiap orang memiliki hak atas perlindungan serta diperlakukan sama. Tujuan dari peraturan tersebut tidak lain adalah untuk memberikan rasa yang nyaman dan kepastian hukum bahwa hat pert indungan ini sudah jelas dan tegas memang harus diberikan. Tentunya baik itu terhadap saksi maupun korban harus sama-sama mendapatkan perlindungan dan harus ditegakan demi keadilan. Beberapa hal yang harus perlu disadari bahwa hubungan korban tidak bisa dipisahkan dari dalam proses peradilan pidana lebih khususnya.

Penjelasan mengenai korban itu sendiri yakni bahwa orang yang mengalami atau dirinya menjalani penderitaan secara batin rnaupun fisik yang didapatkannya serta bisa juga mendapatkan kerugian ekonomi. Tapi pengertian tersebut dapat dikondisikan pada masalah yang terjadi, sebenarnya dalam ha) ini tidak ada penjelasan yang baku. Seperti halnya pada korban kasus pemerkosaan dalam Tindakan tersebut tentunya hal ini dilakukan dengan sebuah pemaksaan untuk melampiaskan nafsu dari pelaku tersebut. Tentunya hal ini menjadikan sebuah tindak kriminal yang bersifat seksual dimana terjadi sebuah pemaksaan hubungan seksual yang menyebabkan korban mendapatkan kerugian mental dan fisiknya. Tidak jarang korban terkadang sampai mengandung anak atau hamil akibat perbuatan dari pelaku tersebut membuat kehamilan yang dialaminya tidak diinginkan oleh korban.

Tentunya hal ini juga membuat psikis atau mental dari korban yang mengandung anak dari perbuatan pelaku ini menjadi terserang atau hancur. Tidak jarang bahwa korban ingin melakukan pengguguran atau aborsi kepada janin yang dikandungnya ini atas dasar penyesalan karena tidak ingin hal ini terjadi. Hal ini terkadangjuga menyebabkan korban menjadi depresi karena hal ini sebagian besar solusi yang diambil dari permasalahan ini biasanya melakukan aborsi guna menghilangkan rasa penderitaan yang tidak diinginkannya ini, mengenai ini tentunya bisa menyebabkan terjadinya pelanggaran hukum. Karena perlu diketahui hal ini juga bisa melanggar hak asasi manusia seperti dalam Pasal 53 angka (I) UU RI No.39 Tahun 1999 pada dasarnya menjelaskan bahwa anak yang sudah ada di dalam kandungan memiliki hak untuk hidup atau melanjutkan kehidupannya. Jadi anak yang didalam kandungan yang di aborsi tentunya kehilangan haknya sebagai makhluk hidup. Aborsi yang dilakukan secara sembarangan sangat membahayakan kesehatan dan keselamatan ibu hamil bahkan sampai berakibat pada kematian (Triwulan, 2009).

Sesungguhnya aborsi yang dilakukan ini merupakan pelanggaran yang sangat keras karena sudah menghilangkan nyawa yang tidak bersalah apalagi masih berupa janin, kasus ini juga melanggar norma masyarakat dikarenakan budaya kita tidak mengajarkan untuk aborsi atau menggugurkan janin. Apalagi banyak diluar sana yang menginginkan untuk mendapatkan bayi dan masyarakat merasa orang yang melakukan aborsi merupakan orang yang tidak menghargai pemberian dari tuhan. Padahal jika kita lihat dari sisi korban pemerkosaan ini, korban sesungguhnya juga mendapatkan hak asasinya diambil dari pelaku tersebut serta tidak sama sekali menginginkan kehamilan ini terjadi. Belurn lagi tekanan dari keluarga dan lingkungan yang didapatnya selama masa keharnilannya yang dianggap hasil dari terlarang ini

Kejadian aborsi tidak mudah dijalankan tetapi kejadian ini adalah kejadian yang mendesak karena ada beberapa faktor yang mendukung. Seperti kasus pemerkosaan tersebut yang dimana korban yang mengalaminya tidak ingin itu terjadi sehingga terjadi kehamilan yang tidak diinginkan. Tentunya kehamilan yang terjadi akibat ulah pemerkosaan ini menjadikan korban menjadi semakin tertekan dan merasa terancam mentalnya baik itu di keluarga maupun di masyarakat. Tidak banyak yang bisa dilakukan oleh korban pemerkosaan karena dia hanya bisa memandangi hasil perbuat dari pelaku tersebut. Korban pemerkosaan yang melakukan tindak aborsi tidakjarang tertangkap oleh penegak hukum karena sudah melakukan pelanggaran dan hal ini mengakibatkan penderitaan seorang korban pemerkosaan yang melakukan tindak aborsi menjadi semakin menderita. Jika di pertimbangkan secara sosial serta psikologis atapun med is, terciptanya pemerkosaan ini tidak terlepas pada kewajiban memberi perlindungan terhadap tiap korban pemerkosaan di masyarakat maka korban juga wajib mendapatkan perlindungan ini. Dikarenakan akibat perbuatan yang ditimbulkan yaitu berupa medis dan sosial psikologis dilakukan dengan keji seperti itu mengakibat korban harus rnenanggung itu semua bahkan keluarga dari korban mendapatkan juga darnpaknya mengenai hal ini, 
dan kemungkinan yang terjadi bahwa korban akan menanggung resiko tersebut sampai akhir hayatnya.

Jika dihubungkan pada aborsi yang dilakukan oleh korban ini sebenarnya faktor yang banyak yang mempengaruhi terjadinya itu karena mental dan psikisnya terserang dan lemah. Sebagaimana yang diatur aborsi merupakan bagian aspek dari kesehatan reproduksi. Seperti pada pasal 72 Ayat 3 UU Kesehatan disana menjelaskan bahwa dasarnya setiap orang berhak menentukan reproduksinya sendiri serat memutuskannya dengan siapa bereproduksi dan kehidupan aman tanpa adanya paksaan dengan pasangan yang sah. Jadi sudah jelas korban yang dirampas reproduksinya secara paksa dan tanpa adanya kernauan dari korban itu sendiri sudah jelas melanggar peraturan yang berlaku tersebut.

Untuk memberikan sebuah jaminan serta perlindungan hukum kepada hak reproduksi tersebut merupakan bentuk dari hak asasi manusia juga. Jadi aborsi bisa dikatakan legal tetapi bersyarat pada korban hamil dikarenakan pemerkosaan guna melindungi hak reproduksi mereka. Perlu diketahui bahwasanya seorang korban pemerkosaan hingga hamil tentunya tetap dilindungi secara hukum. Maka hal ini juga dapat dipertimbangkan dalam segi hak asasi manusia. Yang dimana hak asasi manusia tetap harus didapatkan oleh korban pemerkosaan mengaborsi janin guna melindungi hak asasi manusianya dan reproduksinya karena telah diambil dan hal itu merupakan perampasan secara sadis serta memaksa kehendak dari seseorang. Sejalan dengan yang dikatakan oleh sadli didalam jurnal hukum (Afifah, 2013) bahwa Kekerasan terhadap perempuan menghalangi atau meniadakan kemungkinan perempuan untuk menikmati hak-hak asasi dan kebebasannya. Tentu hal ini bisa diberikan secara legal dalam mengaborsi atau menggugurkan janin dikarenakan secara psikis sudah terancam, yang tentunya tetap menggunakan persyaratan serta prosedur yang legal guna menyelaraskan tujuan untuk melindungi masing-rnasing hak orang guna melindungi mental dan medisnya seperti hak reproduksi mereka dirampas oleh seorang yang tidak bertanggung jawab

Banyak korban yang merasa terancam jiwanya karena hal ini, jadi lebih baik bisa dipertimbangkan untuk bisa melegalkan aborsi ini dengan beberapa syarat yang bisa diperlakukan. hak asasi manusia harus ditegakan guna membangun atau menciptakan rnasyarakat yang aman. Serta perlindungan terhadap korban pemerkosaan harus dilaksanakan sampai tuntas agar tidak terjadinya lagi perampasan terhadap hak asasi manusia di Indonesia.

\section{Sanksi Pidana terhadap Pelaku Aborsi Janin Berdasarkan Hak Asasi Manusia}

Keadilan hukum untuk warga Indonesia tentunya harus dimiliki oleh semua masyarakat, ini merupakan dasar perlindungan sebagaimana memang harus negara memberikan hal ini. Yang tentunya hal tersebut sudah diatur dalam pasal 28 D ayat I UUD 1945 pada dasarnya bukan hanya keadilan saja yang diperoleh melainkan sebuah perlindungan dan tentunya kepastian hukum. Pada perkembangannya tindakan pidana sangat meresahkan masyarakat yang dilakukan oleh pelaku kejahatan, selain seperti yang sudah disebutkan bahwa masyarakat mempunyai hak untuk dilindungi negara bisa juga memberikan sanksi atau hukuman terhadap pelaku pelanggaran ini.

Sebuah sanksi pidana paling banyak dipakai pada saat menjatuhkan hukuman pada seorang yang melanggar hukum di masyarakat (Suyanto, 2018: 45). Pada pengertian sanksi itu sendiri bisa dijelaskan sebagai tanggungan atau lebih tepatnya memaksa seseorang untuk melakukan perjanjian seperti tidak melakukan tindakan pelanggaran tersebut ataupun seperti harus menaati peraturan yang ada di negara. Sanksi ini memiliki rujuan, tidak lain adalah untuk membuat seseorang tidak lagi melakukan tindakan yang melanggar tersebut serta tidak mengulanginya di kemudian hari, Hal tersebut mernpakan tanggung jawab yang diberikan oleh penegak hukum untuk membayar kesalahan yang diperbuatnya tersebut.

Pada dasarnya sanksi pidana merniliki tujuan untuk menekan masyarakat untuk tidak melakukan tindakan pidana yang melanggar ini. Tetapi masih saja aturan yang dibuat sangat sulit untuk dilaksanakan. Hal ini terjadi dikarenakan memang dasarnya ada beberapa pelaku yang memiliki keberanian serta ketidakmauan untuk berubah dalam dirinya, yang terus mengulanginya secara terus menerus padahal sudah mendapatkan sanksi tetapi masih saja melakukan pelanggaran tindakan pidana ini. Saat masa sekarang kadang banyak menuntut akan ingin memiliki pengakuan serta penghormatan pada hak asasi manusia begitu sangat terlihat dikarenakan munculnya gelombang demokrasi serta mengenai globalisasi. Permasalahan pidana semakin penting untuk dibicarakan serta orang-orang menilai pidana sebagai suatu hal yang mengagumkan saat membicarakannya. Berbicara mengenai berbagai macarn tindakan pelanggaran pidana yang terjadi, salah satunya adalah aborsi. Tentunya hal 
ini sangat melanggar hukum pidana seperti yang kita ketahui pada pasal 346 KUHP disana berisi tentang beberapa hal yang menyangkut mengenai tentang pelanggaran ini.

Pada dasarnya tidak bisa seorang wanita yang hamil menggugurkan ataupun mematikan kandungan itu sendiri maupun banruan dari orang lain. Dan sangatjelas hal ini melanggar aturan yang ada di dalam KUHP itu sendiri bisa disebut hal ini termasuk tindakan pembunuhan dikarenakan sudah rnerenggut nyawa seseorang yang ada di dalam kandungan. Kasus seperti tersebut tentunya sudah merampas nyawa seorang apalagi berupa janin yang dimana janin tetap memiliki hak untuk hidup di dunia. Hal seperti ini pun melanggar hak asasi manusia, karena sungguh dan benar-benar merampas hak orang untuk hidup.

Untuk menghindari tindakan aborsi tersebut, tentunya negara memiliki aturan khusus dalam menanganinya yairu ada di dalam KUHP pada pasal 346 sampai dengan 349. Di dalam pasal tersebut sangat jelas menjelaskan bahwa tindakan pidana aborsi dapat dikenai sanksi. Hukuman sanksi yang diberikan sangat tegas yairu ketiga ada seorang wanita yang menggugurkan kandungan dengan sengaja dapat di penjara kurungan paling lama lima belas tahun. Adapun jika seseorang mernbantu tindakan aborsi ini juga dapat dipidana sebagaimana yang diatur dalam Pasal 349 di pasal tersebut menjelaskan bahwa jika seorang dokter ataupun bidan dapat dikenai sanksi maka sanksi pidana yang diberikan yaitu pada pasal tersebut ditambah pada sepertiga. Secara pandangan umum masalah ini banyak menimbulkan pro dan kontra di masyarakat. Mengingat aborsi ini terjadi akibat faktor yang tidak diinginkan oleh seseorang dikarenakan hasil dari paksaan yang dimana hal ini mengambil hak seseorangjuga. Apalagi kasus ini ditanggung begiru berat oleh seorang wanita yang hamil akibat pernerkosaan yang terjadi Belum lagi Iuka batin dan mental yang dibawanya hingga akhir hayatnya.

Jika di dalam dunia Kesehatan kasus ini diberikan aturan khusus dan memiliki pengecualian terhadap tindak pidana aborsi ini. Terlebih hal ini diatur dalam Peraruran Pemerintah Republik Indonesia omor 61 Tahun 2014 Tentang Kesehatan Reproduksi Bab IV pada pasal 34 disana ada beberapa hal yang dapat dijadikan acuan ataupun alasan unruk melakukan aborsi itu legal Adapun beberapa hal yang jelaskan seperti yang terkandung dalam pasal tersebut seperti adanya keterangan dari penyidik atau psikolog mengenai tentang dugaan perkosaan serta usia kehamilan sama dengan kejadian perkosaan. Adapun dalam pasal 35 dan 36 ada beberapa hat menjelaskan bahwasannya aborsi ini dilakukan berdasarkan indikasi adanya kedaruratan medis akibat pemerkosaan serta praktis aborsi yang arnan serta bermutu dilakukan oleh dokter dengan sesuai standar yang berlaku.

Tetapi dengan maksud alasan untuk pembenaran pada aborsi, harus ada bukti dari surat keterangan dokter, penyidik serta psikolog namun semua tersebut belum memberikan kepastian hukum, baik hal ini bagi yang melakukan aborsi ataupun dokter yang memberikan bantuan medis dengan tindakan aborsi ini. Dikarenakan pada dasarnya yang dibuktikan agar terpenuhinya delik atas pemerkosaan ini adalah unsur berupa kekerasan serta ancaman berupa kekerasan iru sendiri. Dari penjelasan diatas mengenai aborsi, maka dapat diartikan bahwa jika seorang wanita tidak memenuhi delik pemerkosaan maka wanita tersebut atau orang yang melakukan aborsi dapat dipidana dikarenakan tidak adanya alasan karena tidak memenuhi delik pemerkosaan. Yang membantu dalarn melakukan tindak aborsi ini juga terancam di hukum pidana. Sebagaimana yang dimaksud bahwa yang melakukan tindak pidana aborsi dapat dipidana dengan sanksi 10 tahun dipenjara.

Menggugurkan kandungan atau yang disebut aborsi dengan sengaja melakukannya baik itu memakai obat dan cara melalui medis lainnya ataupun memakai secara tradisional. Walaupun dengan cara itu dilakukan tetap saja pada dasarnya hal tersebut termasuk kedalam tindak pidana pembunuhan serta hal ini tentunya sangat melanggar hukum (Waluyadi, 2005: 50). Intinya bahwa hal aborsi ini sudah terdapat di dalam KUHP, tetapi berdasarkan beberapa faktor mengenai aborsi ini menjadi mendapatkan alasan-alasan tertentu yang dimana salah satu faktornya adalah didasari oleh keselamatan jiwa seseorang, karena perlu dipaharni seorang yang memiliki kandungan diluar dari kemauannya sangatlah tertekan baik itu secara mental serta ketidaksiapannya untuk menerika keadaan seperti itu. Menyebabkan perasaan yang bergejolak karena hak asasi sebagai manusia telah dirampas oleh orang lain.

Secara yuridis hal ini sudah jelas bahwa HAM begitu sangat terkait dalam sesuatu yang begitu mendasar bagi kehidupan pada manusia. Hak asasi manusia adalah secara kodrat telah melekat dari dalam diri rnanusia dan tidak bisa rampas oleh orang lain. Karena ham merupakan pemberian dari Tuhan Yang Maha Esa. Maka patut untuk di junjung serta tidak dirampasnya hak dari masingmasing orang di manapun itu berada. Hak asasi sangat erat baik itu dalam diri manusia maupun 
negara. Dalam kasus ini terjadi pergesekan kepentingan antara melindungi hak asasi dari janin itu yang telah turnbuh dalam kandungan dan dari hak seorang ibu yang menginginkan terlepas pada beban psikologis serta sosial yang didapatnya. Jika pada dasamya aborsi dipakai hanya untuk sesuatu yang tidak memiliki unsur mengharuskan untuk diaborsi melainkan hanya tidak ingin memiliki anak dan mengambil paksa janin tersebut tentunya melanggar hak asasi manusia itu sendiri dan dapat dilakukan tindak pidana kejahatan pembunuhan

\section{SIMPULAN DAN SARAN}

\section{Simpulan}

Dari pemaparan hasil penelitian diatas dapat disimpuJkan sebagai berikut:

a. Perlindungan hukum terhadap korban pemerkosaan aborsi janin ditinjau dari perspektif HAM Hak Asasi Manusia jika dilihat dari hak asasi manusia ini melakukan tindakan aborsi adalah merupakan hal yang tidak bisa dimaafkan dan tentunya melanggar hak asasi dikarenakan diambilnya nyawa seseorang secara paksa yang bisa disebut dengan melakukan pembunuhan. Tetapi dalam kasus ini sangatlah berbeda dikarenakan korban melakukan aborsi didasarkan dengan mereka telah menjadi korban pemerkosaan yang menyebabkan sampai terjadinya suatu kehamilan yang tidak diinginkan. Menyebabkan mental dan psikis korban menjadi terancam karena kehamilan yang tidak diinginkannya ini. Dalam kasus ini tentunya dapat dilihat dalam hal mengenai perlindungan warga negara yang dimana diatur dalam perlindungan korban pada pasal 3 UUD Nomor 13 Tahun 2006 menjelaskan tentang perlindungan saksi dan korban. Seperti yang telah dijelaskan disini, korban pemerkosaan hingga menyebabkan terjadinya kehamilan atau mengandung anak dari hasi paksa dari seorang tentunya sebagai korban dapat perlindungan sebagaimana yang diatur dalam pasal tersebut.

b. Sanksi pidana terhadap pelaku aborsi janin berdasarkan Hak Asasi Manusia sebagaimana yang dijelaskan pada pasal 346-349 KUHP menjelaskan mengenai kejahatan kepada nyawa adalah sebuah dasar untuk menjatuhkan atau memberikan sanksi kepada pelaku yang menghilangkan nyawa orang dengan cara aborsi. Serta sanksi yang dapat diberikan yaitu kurungan paling lama lima betas tahun. Ada Pula jika seorang membantu tindakan aborsi ini juga dapat dipidana seperti yang diatur pada Pasal 349 di pasal tersebut menjelaskan bahwa jika seorang dokter ataupun bidan dapat dikenai sanksi maka sanksi pidana yang diberikan yaitu pada pasal tersebut ditambah pada sepertiga. Untuk menambah ketegasan sanksi yang berlaku hat ini terdapat juga dalam sisi kesehatan yang dirnana diatur didalam UUD Kesehatan Nomor 36 tahun 2009 yang dimana sanksi diberikan dari sudut pandang kesehatan yaitu jika terjadi kesesuaian unsur maka pada pasal ini dapat diberikan sanksi berupa pidana penjara paling lama sepuluh tahun serta denda paling banyak yaitu Rp.1.000.000.000 (satu milyar rupiah).

\section{Sanan}

Dari hasil penelitian ini terdapat dua saran yaitu

a. Peran pemerintah Diharapkan pemerintah mempertimbangkan kembali unsur-unsur yang terkait dalam Kitab Undang-Undang Pidana mengenai Kejahatan Terhadap Nyawa, agar tidak memiliki hanya saja pemikiran mengenai tindak pidana aborsi dari sisi yang secara umum, sehingga tidak terjadi penafsiran aturan yang berbeda-beda dan mempertimbangkan kembali peraturan perundang-undangan yang ada, baik mengatur mengenai masalah aborsi itu sendiri khususnya terhadap aborsi yang merupakan hasil dari pemerkosaan, sehingga Indonesia memiliki peraturan khusus dan pasti mengenai tindak pidana aborsi karena pemerkosaan.

b. Peran masyarakat Tentunya kepada masyarakat kesadaran hukum mengenai hal-hal yang akan maupun sering terjadi di masyarakat lebih meningkat serta diharapkan masyarakat lebih bijak dan mampu memahami aturan dengan baik terkait segala tindak pidana baik khususnya mengenai pemerkosaan dan aborsi itu dan bagi keluarga atau masyarakat yang lingkungannya terdapat korban pemerkosaan diharapkan lebih bijak dalam rnenilai agar tidak kembali menjadikan korban pemerkosaan sebagai pemikul dari beban itu sendiri karena ha! ini dapat memiliki keterkaitan terhadap psikis korban itu sendiri. 


\section{DAFTAR PUSTAKA}

Abdullah, R. (2001). Perkembangan hak asasi manusia dan keberadaan peradilan hak asasi manusia di Indonesia. Ghalia Indonesia, Jakarta.

Afifah, W. (2013). Perlindungan Hukum Bagi Perempuan Korban Perkosaan Yang Melakukan Aborsi. Jurnal Ilmu Hukum, Vol. 9(18).

Duwi, H. (2017). Asas-asas Hukum Pidana dan Hukum Penitensier di Indonesia: (Dilengkapi dengan Evaluasi Pembelajaran dalam Bentuk Teka-Teki Silang Hukum dan Disertai dengan Humor dalam Lingkup Ilmu dan Pengetahuan tentang Hukum) (Cetakan I). Hawa dan Ahwa, Pekan Baru.Sari, R. Y. (2013). Aborsi Korban Perkosaan Perspektif Hukum Islam Dan Hak Asasi Manusia. The Indonesian Journal of Islamic Family Law, Vol. 3(1).

Rasjidi, L \& Rasjidi, L. S. (2016). Dasar-Dasar Filsafat dan Teori Hukum. PT Citra Aditya Bakti, Bandung.

Sofian, A. (2011). Rustam Mochtar Sinopsis Obstetri: Obstetri Fisiologi Obstetri Patologi Jilid 1 (Jilid I). Buku Kedokteran EGC, Jakarta.

Suyanto. (2018). Pengantar Hukum Pidana (Cetakan 1). Deepublish, Yogyakarta.

Susanti, Y. (2012). Perlindungan Hukum Bagi Pelaku Tindak Pidana Aborsi (Abortus Provocartus) Korban Pemerkosaan. Jurnal Ilmu Hukum Syiar Hukum, Vol. 16(2).

Triwulan, T. T. (2009). Analisis Hukum Islam Terhadap Praktik Aborsi Bagi Kehamilan Tidak Diharapkan (KTD) Akibat Perkosaan Menurut Undang-Undang Nomor 36 Tahun 2009 Tentang Kesehatan. Universitas Diponegoro, Semarang.

Utami, tanti. K \& Mulyana. (2015). Tanggung Jawab Dokter Dalam Melakukan Aborsi Tanpa Seijin Ibu Yang Mengandung Atau Keluarga Dalam Perspektif Hukum Positif Di Indonesia. Jurnal Mimbar Justitia, Vol. 1(2).

Waluyadi. (2005). Ilmu kedokteran kehakiman: dalam perspektif peradilan dan aspek hukum praktik kedokteran. Djambatan. 